\title{
The geometry in the urban layout of the Roman Como and Verona: the same solution to different problems
}

\author{
A. C. Sparavigna ${ }^{1}$ and R. Marazzato ${ }^{2,3}$ \\ ${ }^{1}$ Dipartimento di Scienza Applicata e Tecnologia, Politecnico di Torino, Torino, Italy \\ 2 Dipartimento di Scienze Matematiche "G. L. Lagrange", Politecnico di Torino, Torino, Italy \\ ${ }^{3}$ Dipartimento di Management, Università degli Studi di Torino, Torino, Italy
}

\begin{abstract}
This work proposes a possible use of the same geometry, based on the fundamental Pythagorean triple 3,4 and 5, to have the proper planning of the Roman towns of Como and Verona. The towns had been located in quite different environmental conditions, but it seems that the solution that the Roman surveyors used was the same. Previously, a possible orientation of these towns according to solstices had been proposed. Here we consider this orientation in the framework of the geometrical approach too.
\end{abstract}

Keywords: Centuriation, Orientation of Roman colonies.

\section{Submitted SSRN on 25 July 2019}

The plan of the Roman colonies was implemented by means of a land survey method which is known as limitation or centuriation. It is characterized by a layout in the form of a square or rectangular grid, created by parallel and perpendicular roads and canals, which subdivided the settlement into insulae, which were the house-blocks in the towns or the agricultural plots in the countryside. In some cases these plots were allocated to Roman army veterans [1]. Of course, the choice of the place of a town or colony was dictated by the local environment and the presence of rivers and roads.

To subdivide the land for the colony, the surveyor (gromaticus) first identified a central viewpoint, known as the umbilicus agri or umbilicus soli. He then took up his position there and, after assuming a specific orientation, defined the territory with the following names: ultra, the land he saw in front of him; citra, the land behind him; dextera, the land to his right; sinistra, the land to his left $[2,3]$. He then traced two road axes perpendicular to each other. The first was called decumanus maximus, the second the cardo maximus. After a grid of parallel and perpendicular roads were traced to subdivide the land into insulae. According to the Latin writer Frontinus [3], who was referring Varro, the Romans inherited the manner to subdivide the land from the Etruscan Doctrine. He also tells the determination of the two main axes of the centuriation, that is, of the decumanus and cardo, was made by an aruspex that was a soothsayer or diviner. 
We read in [3] that the decumanus runs from oriens to occasus, that is from the sunrise to the sunset. After these words, some scholars, such as Barthel [2], argued for an orientation of the decumanus towards the point of the horizon were the sun was rising, secundum coelum, but other scholars maintained that the orientation was just dictated by the local environment or by the main roads of the area, as stressed by Le Gall and Castagnoli $[4,5]$. In any case, to have the regular grids of the limitation matching the local environments, secundum naturam, the Roman surveyors had to rotate the grids. The surveyors had some rules, that we can find in the literature of the Gromatici, which are defined as varatio [6,7]. Varatio is also mentioned by Vitruvius [8].

According to [9], the term varatio, also written uaratio, refers to a process of oblique surveying. As told by [9], it has been shown by Anne Roth-Congès [10] that at least two approaches were employed; there was a uaratio fluminis [11], by means of which the distance of an inaccessible point could be calculated by the construction of right angled triangles, and there was a uaratio in agris diuisis, that the surveyors could made by means of lines "along the hypotenuse of right angled triangles defined in a rectangular coordinate system" [9]. This second uaratio is the one which is statistically analyzed in [9]. As stressed by John Peterson, when introducing his analysis, the variety of observed oblique relationships, that is $(1: 1,1: 2,2: 3,3: 4 \ldots)$, is limited. For what concerns a possible orientation with a sighting by stars [12], Peterson considers it an approach "which does not seem very feasible, since it would have obliged surveyors to work at night".

Besides the study of varatio concerning the Hadrian's Wall and the Wetterau Limes [9], we can find the varatio considered for the orientation of the Roman towns in Spain [13]. In [14], the approach of [13] is considered with a specific aim. The authors of [13], that have studied the orientation of 81 Roman towns in the Iberian Peninsula having varatio angles with aspect ratios up to 12:12, "want to discern whether the orientations were astronomical, purely geometrical, or if geometry could have fostered astronomical aims by using selected and well-known angles to trace lines that fitted the desired astronomical purposes." The work is, according to their words, "an attempt to shed more light to the issue of the orientation of Roman towns by combining two hypotheses that, in contrast to what it might seem, could be complementary but not contrary."

Of course, also for the Roman towns in Italy, the study of their varatio could be an interesting research. The reason of the research could be the same as for [14]. In the case we have a town that seems oriented, for instance, to the sunrise on solstices, we could ask ourselves if this town was subjected to a procedure of varatio too. In the case of a positive answer, a further question could be: is this varatio also the best for the orientation secundum naturam?

As a consequence, the aim of our paper is not that of analyzing all the cases, but just to attract the interest of the researchers of the topic of varatio into the layout of Roman towns in Italy.

Among the towns that have a possible solstice orientation, we find Como and Verona [15]. For what concerns Como, we know that it was around the 1st century BC that the territory became subject to Rome. In origin, the town was situated on the nearby hills. It was moved to the current location by Julius Caesar. The newly founded town, in 59 BC, was named Novum Comum.

In the case of Verona, its territory became Roman about 300 BC. Verona became a Roman colony in $89 \mathrm{BC}$, and it was classified as a municipium in $49 \mathrm{BC}$. 


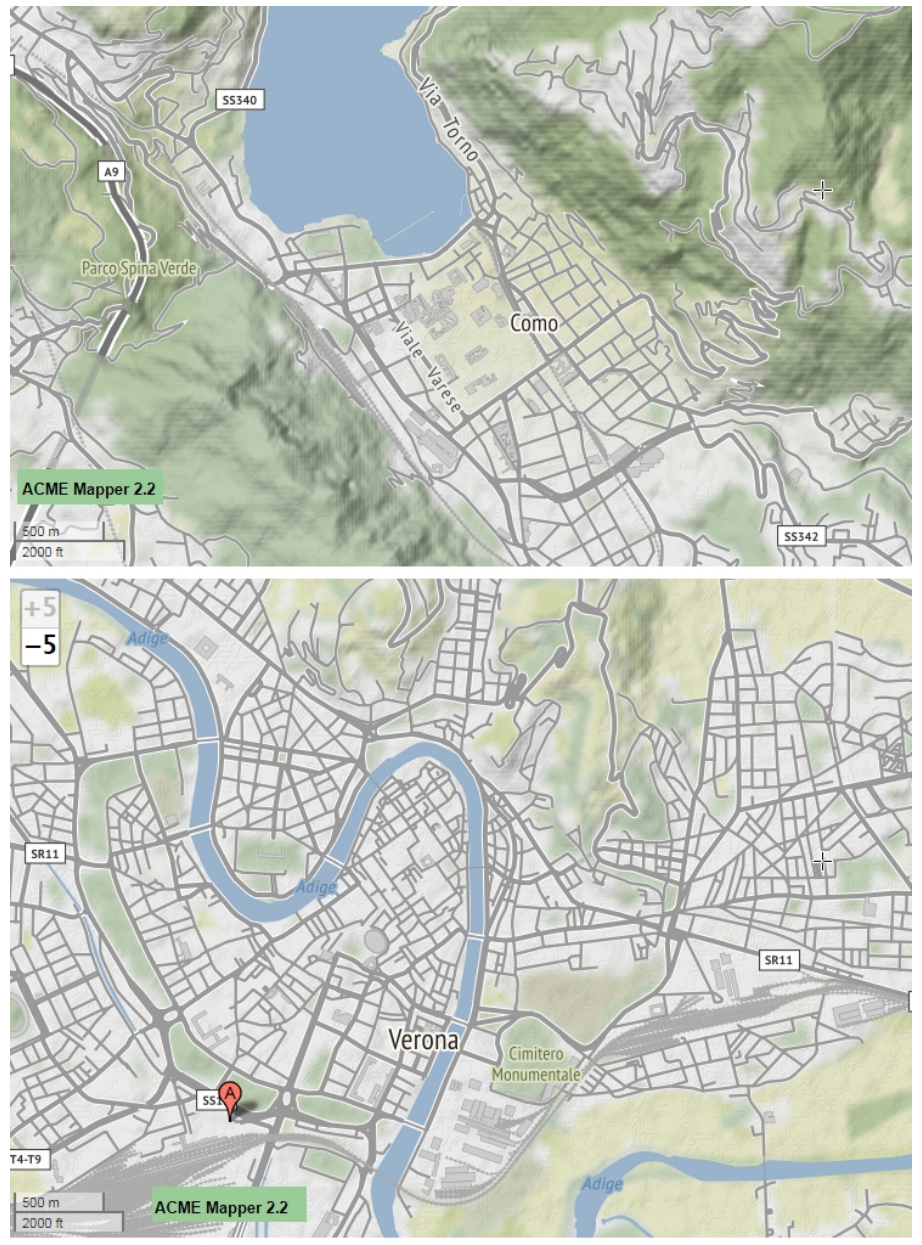

Figure 1: Thanks to Acme Mapper, https://mapper.acme.com, we can appreciate very well the terrain of Como (upper panel) and Verona (lower panel). The core of the Roman Verona is in the bend of the Adige river.
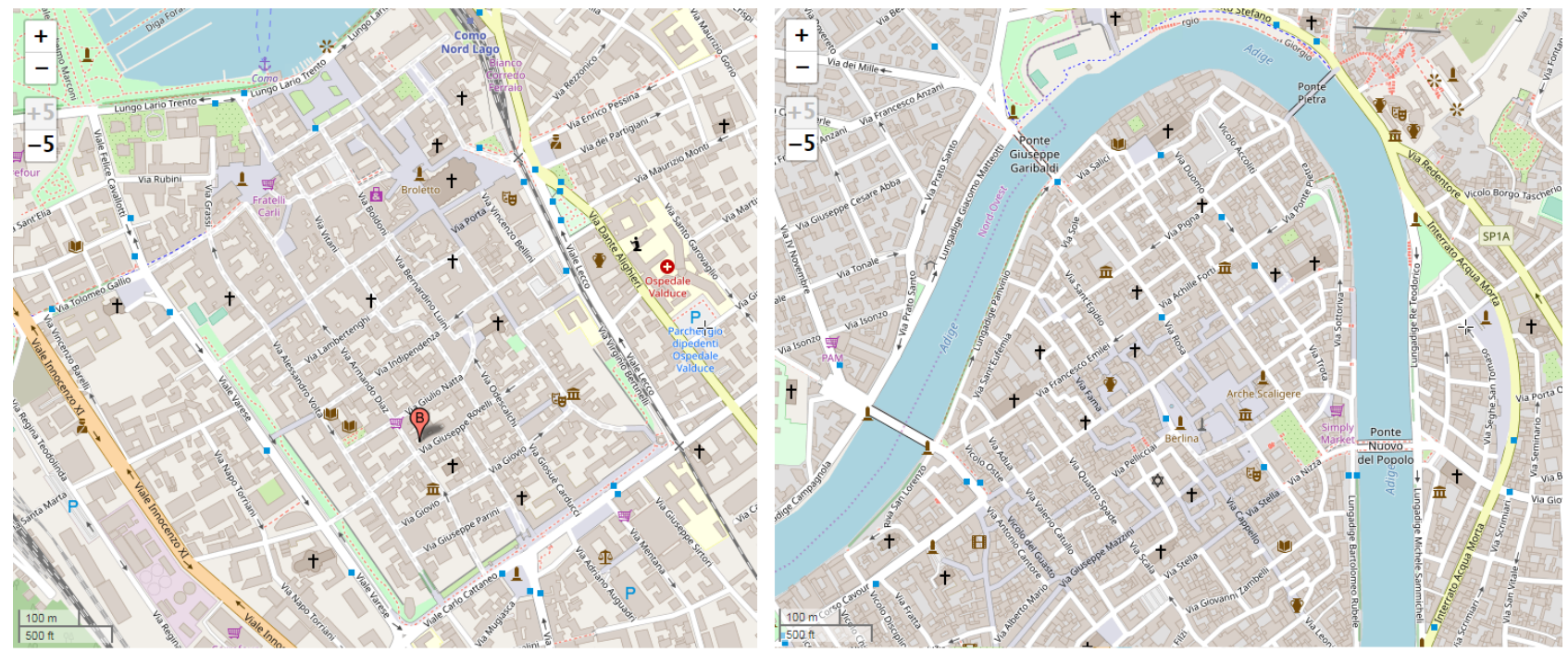

Figure 2. Thanks to Acme Mapper and (C) OpenStreetMap contributors, we can see the layout of the two towns; on the left Como is shown, and on the right Verona. OpenStreetMap (CC BY-SA). The same for the images here given. 
As we can see from the Figure 1, the terrain of the two towns is quite different. But, as shown by the Figure 2, the layout is the same. So let us consider if we can find a possible geometry of this layout. We assume that the insulae of the centuriation were squares and that the squares had, more or less, the same size. Let us note that, during the centuries, the insulae had been deformed and therefore it is difficult to see today the original Roman layout perfectly maintained in the town.

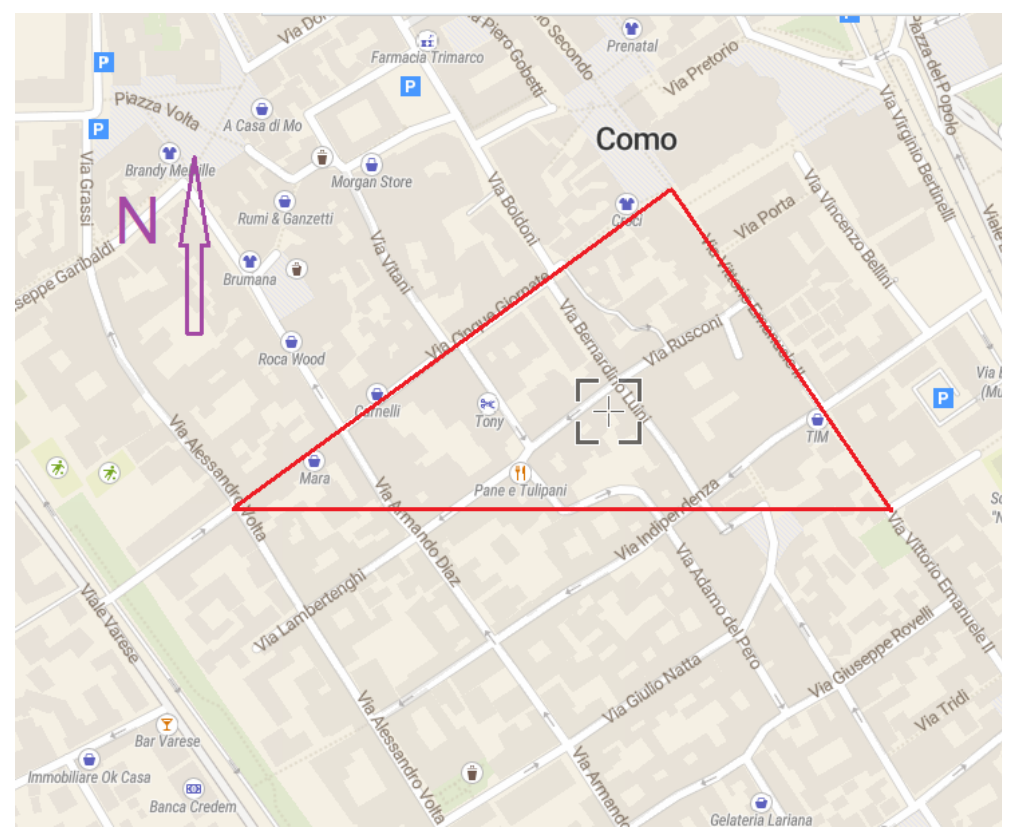

Figure 3: Como and its rectangular triangle 3,4 and 5 shown on a epsg.io map (C) MapTiler (C) OpenStreetMap contributors).

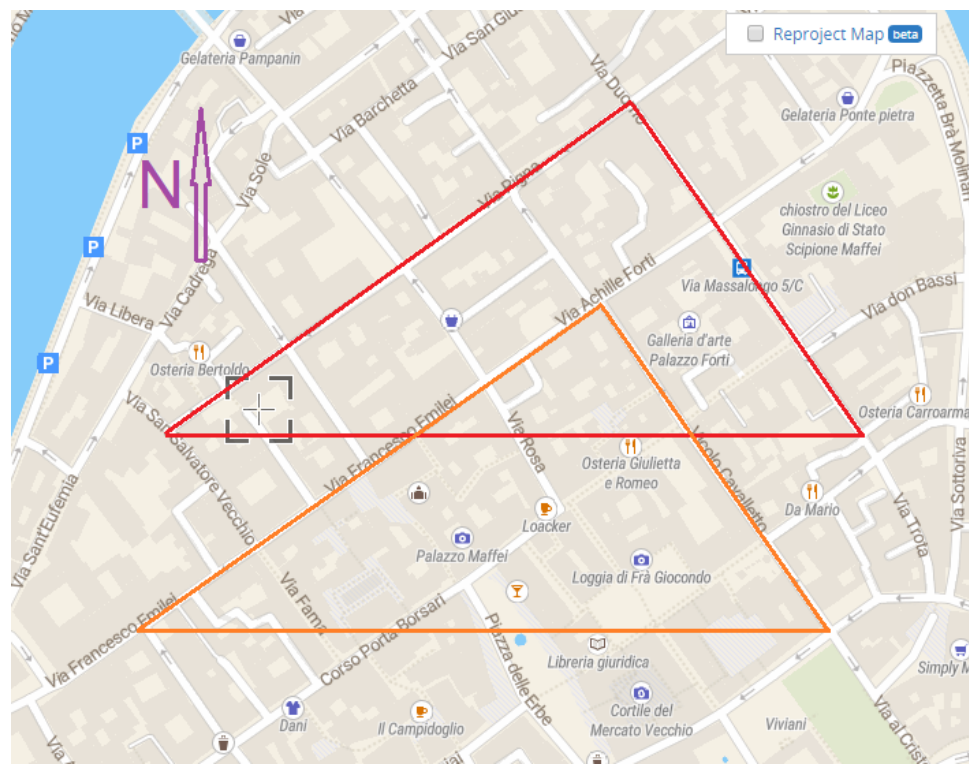

Figure 4: The same rectangular triangle 3,4 and 5 in Verona shown on a epsg.io map (@ MapTiler (C) OpenStreetMap contributors). 
In the Figures 3 and 4 we have found rectangular triangles which could have been determined by the varatio. The hypotenuses are coincident to the east-west direction. The catheti seem to correspond to 3 and 4 insulae respectively. So we have that the rectangular triangle is that of the fundamental Pythagorean triple 3,4 and 5. In the figure 5 we show a corresponding ideal scheme. The two catheti give the directions of the decumanus and the cardo. The angle that the decumanus and the hypotenuse form is given by $\alpha=\arctan (3 / 4)=36.87^{\circ}$. Therefore, the azimuth from true North, of the decumanus is $53,13^{\circ}$.

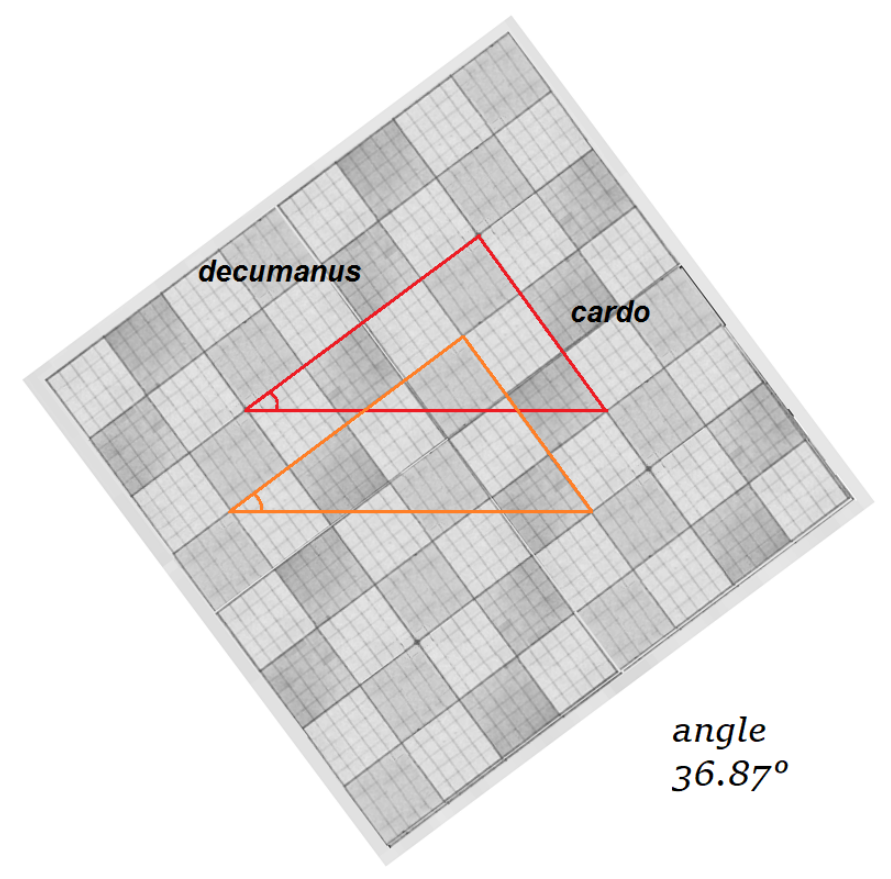

Figure 5

As previously told, these two tows have been proposed as oriented to solstices [15-17]. So let us consider the sunrise azimuth on summer solstice at Como and Verona, for the years of their foundations. We use software CalSKY, which gives sunrise and sunset directions on an astronomical horizon. The angles are given according to the true azimuth, that is, from true North.

\begin{tabular}{|l|lllll|}
\hline 25 Jun 59BC & Rise $: \begin{array}{c}4 \mathrm{~h} 17.5 \mathrm{~m} \\
\mathrm{az}=53.7^{\circ}\end{array}$ & Set $\begin{array}{c}20 \mathrm{~h} 04.2 \mathrm{~m} \\
\mathrm{az}=306.3^{\circ}\end{array}$ & Como \\
\hline 25 Jun 89BC & Rise $: \begin{array}{c}4 \mathrm{~h} 11.1 \mathrm{~m} \\
\mathrm{az}=54.0^{\circ}\end{array}$ & Set & $\begin{array}{c}19 \mathrm{~h} 54.7 \mathrm{~m} \\
\mathrm{az}=306.0^{\circ}\end{array}$ & Verona \\
\hline
\end{tabular}

We can see that, within an error of one degree, we are close to the direction of the decumanus given in the Figure 5 (ideal case). Now, let us consider the Decumanus maximus of Como, today via Indipendenza: it has an azimuth from true North of $55^{\circ}$, evaluated by means of Google Earth. In Verona, the Decumanus (Corso Sant'Anastasia) has an azimuth of $54,7^{\circ}$. 
These angles are, within a degree, in agreement. The fact that the towns were planned according to the varatio 3:4 seems well posed. But that this varatio was chosen to have the towns aligned to sunrise on solstices could be simply a coincidence. Let us conclude observing that in the case of Como, the natural horizon is quite different from the astronomical horizon, so the alignment of the decumani and the sun cannot be observed. An astronomical orientation has therefore to be considered as an ideal one.

\section{References}

[1] Haverfield, F. (1913). Ancient town - planning, Oxford, The Clarendon Press, 1913, available athttp://www.gutenberg.org/files/14189/14189-h/14189-h.htm

[2] Barthel, W. (1911). Römische Limitation in der Provinz Africa, 1911, CXX, pp. 39-126. Carl Georgi Verlag, Bonn.

[3] In the Corpus Agrimensorum Romanorum, which is the Roman book on land surveying collecting works by Siculus Flaccus, Frontinus, Aggenus Urbicus, Hyginus Gromaticus and other writers, we find the following (ex libro Frontini secundo): Limitum prima origo, sicut Varro descripsit, a disciplina Etrusca; quod aruspices orbem terrarum in duas partes diuiserunt, dextram appellauerunt quae septentrioni subiaceret, sinistram quae ad meridianum terrae esset, ab oriente ad occasum, quod eo sol et luna spectaret, sicut quidam architecti delubra in occidentem recte spectare scripserunt. Aruspices altera linea ad septentrionem a meridiano diuiserunt terram, et a media ultra antica, citra postica nominauerunt.

[4] Castagnoli, F. (1958). Le ricerche sui resti della centuriazione. Storia e Letteratura. Roma 1958.

[5] Le Gall, J. (1975). Les romains et l'orientation solaire. MEFRA 87-1975-1, p. 287-320.

[6] Libertini, G. (2018). Gromatici Veteres - Gli Antichi Agrimensori - Traduzione in italiano con commenti, figure, schemi e illustrazioni a cura di Giacinto Libertini e con presentazione di Gianluca Soricelli. Istituto Di Studi Atellani, Frattamaggiore, Naples \& Copernican Editions

[7] B. Campbell, The Writings of the Roman Land Surveyors. Introduction, Text, Translation and Commentary (Journal of Roman Studies Monograph 9). London: Society for the Promotion of Roman Studies, 2000.

[8] M. Vitruvii Pollionis De architectura libri decem. Cum notis, castigationibus \& observationibus Guilielmi Philandri integris; Danielis Barbari excerptis, \& Claudii Salmasii passim insertis. Apud Ludovicum Elzevirium, Amstelodami, 1649.

[9] Peterson, J. W. (2001). Design and Performance of the Varatioscope. BAR International Series, 931, 269-272.

[10] Roth Congés, A. (1996). Modalités practiques d'implantation des cadastres romains: quelques aspects. Mélanges de l'école française de Rome 108: 299-422.

[11] Bouma, J. (1993). Marcus lunius Nypsus: Fluminis varatio, Limitis repositio: introduction, text, translation, and commentary (Vol. 77). Peter Lang Pub Inc. www.peterlang.com/view/title/39249

[12] Margary, I. D. (1973). Roman Roads in Britain (Revised Edition). London: John Baker. 
[13] Orfila, M., Chávez, Mª., \& Sánchez, E. H. (2014). Las estructuras ortogonales de nueva planta en época romana. De la varatio y sus variaciones. Granada, ISBN: 978-84-338-56-9. Publisher: Universidad de Granada; Servicio de Publicaciones de la Universidad de la Laguna y la Universidad de Valladolid.

[14] Rodríguez-Antón, A., Pons, M. O., González-García, A. C., \& Aviles, J. B. (2019). The Uaratio and Its Possible Use in Roman Urban Planning to Obtain Astronomical Orientations. In Archaeoastronomy in the Roman World (pp. 103-120). Springer, Cham.

[15] Sparavigna, Amelia Carolina, Roman Towns Oriented to Sunrise and Sunset on Solstices (May 8, 2016). Available at SSRN: https://ssrn.com/abstract=2777118 or http://dx.doi.org/10.2139/ssrn.2777118

[16] Morandotti, L. (2011). Quel solstizio che disegnò il volto di Como. Corriere di Como.

[17] Gaspani, A. (2009). Verona. Origini storiche e astronomiche. Edizioni della Vita Nova di Giovanni Perez. 